\title{
SYNTHESIS AND CHARACTERIZATION OF A TETRAHEDRAL AND MONOMERIC MONOBUTYLTIN COMPOUND WITH A-HYDROXYISOBUTYRIC ACID
}

\author{
ROBERTO SANTOS BARBIÉRIII, VILMA REIS TERRA2 , ALLAN KARDEC CARLOS DIAS ${ }^{3}$,WALCLÉE DE \\ CARVALHO MELO
}

\author{
${ }^{1}$ Centro Universitário de Caratinga-UNEC, 35300-047, Caratinga-MG, Brazil - robertosbarbieri@funec.br \\ ${ }^{2}$ Centro Universitário de Vila Velha - UVV, 29125-000, Vila Velha-ES, Brazil \\ ${ }^{3}$ Centro Universitário de Caratinga - UNEC, 35300-047, Caratinga-MG, Brazil \\ ${ }^{4}$ Universidade Federal de Lavras - UFLA, 37200-000, Lavras-MG, Brazil
}

\begin{abstract}
The monobutyltin compound $\left[\mathrm{BuSnLCl}_{2}\right], \mathrm{L}=\mathrm{Me}_{2} \mathrm{C}(\mathrm{OH}) \mathrm{COO}^{--}$, was prepared and characterized by elemental analysis of carbon, hydrogen, chlorine and tin, and infrared, ${ }^{119 m}$ Sn-Mössbauer and ${ }^{119 m}$ Sn-NMR spectroscopies. In the compound, a tetrahedral tin species, L is coordinated monodentatedly by the oxygen of the deprotonated hydroxyl of the carboxylic group. The compound was studied by the application of TG and DSC in dynamic atmosphere of helium. The thermal decomposition mechanism for the compound and TG curve suggests the formation of tin in accordance with their stoichiometry. The Mössbauer parameters of complexes are in agreement with a monomeric structure for the complex in the solid state.
\end{abstract}

Keywords: organotin compound, tin isobutyric acid compound, thermal decomposition.

\section{INTRODUCTION}

The $\alpha$-hydroxycarboxylic acids are ligands potentially polydentated, that can bond to metals, enabling the synthesis of compounds with varied structures, for which the geometry and the coordination number are governed by the size and for the ramification degree of the ligand. ${ }^{1}$ In the years 1995-2005, we have developed systematic works about the synthesis and characterization of organotin compounds derived from $\alpha$-hydroxycarboxylic acids ${ }^{2-5}$, which have shown efficient microcide activity on fungi and pathogenic bacteria in agriculture and in humans. ${ }^{6-8}$ The present investigation relates to the preparation and characterization of a new complex $\left[\mathrm{BuSnLCl}_{2}\right], \mathrm{L}=\mathrm{Me}_{2} \mathrm{C}(\mathrm{OH}) \mathrm{COO}$, characterized by elemental analysis of carbon, hydrogen, chlorine and tin, by infrared, ${ }^{119 m} \mathrm{Sn}$-Mössbauer and ${ }^{119 m} \mathrm{Sn}$-RMN spectroscopies, and the applications of TG and DSC techniques in dynamic helium atmosphere.

\section{EXPERIMENTAL}

The TG curve was recorded using Shimadzu TGA-50 model thermogravimetric analyzer in the range of $25-700{ }^{\circ} \mathrm{C}$ at heating rate of $20 \mathrm{~K}$ $\mathrm{min}^{-1}$ and in a dynamic atmosphere of helium with a flow rate of $20 \mathrm{~mL} \mathrm{~min}{ }^{-1}$. The initial sample masses used were $3-4 \mathrm{mg}$.

A Shimadzu DSC-50 differential scanning calorimetry analyzer was used to record the DSC curves. The experimental conditions were: $25-200{ }^{\circ} \mathrm{C}$ temperature range, $\beta=10 \mathrm{~K} \mathrm{~min}^{-1}$ heating rate, helium purging with a flow of $50.0 \mathrm{~mL} \mathrm{~min}^{-1}$. The initial sample masses were $5-6 \mathrm{mg}$.

The melting point was determined on a FP-2 Mettler system.

The infrared spectrum of the complex was recorded between $5000-200 \mathrm{~cm}^{-}$ ${ }^{1}$, using a Perkin Elmer Paragon 1000 spectrophotometer, in CsI pellets.

The X-ray fluorescence characterization of the TG analysis was performed by means of a Rigaku-Geigerflex spectrophotometer.

The elemental analysis of carbon and hydrogen was carried out using Perkin Elmer 2400CHN Elemental Analyzer.

Chlorine determination was done by neutron activation analysis. The sample was irradiated in the central tube of the Triga-3 reactor and the measurement was performed applying a Low Lewel $\alpha / \beta$ Counting System Model 2200 Canberra proportional detector, at the Nuclear Development Technology Centre, of CNEN (National Nuclear Energy Commission), in Belo Horizonte-MG, Brazil.

The tin determination was performed by atomic absorption using a Hitachi Z-8200 spectrometer.

The ${ }^{119 m}$ Sn-Mössbauer spectra were provided by a constant acceleration spectrometer equipped with $\mathrm{BaSnO}_{3}$ source, at $85 \mathrm{~K}$.

The ${ }^{119 m}$ Sn-NMR spectrum was obtained with a Bruker DRX $400 \mathrm{MHz}$ Avance spectrophotometer, using $\mathrm{C}_{5} \mathrm{D}_{5} \mathrm{~N}$.

The complex $\left[\mathrm{BuSnLCl}_{2}\right]$ was synthesized reacting $\alpha$-hydroxyisobutyric acid, $\left(\mathrm{CH}_{3}\right)_{2} \mathrm{C}(\mathrm{OH}) \mathrm{COOH}$, and monobutyltin trichloride, $\mathrm{BuSnCl}_{3}$, in 1:1 molar ratio. The carboxylic acid was added to stirred acetonitrile solution and after adding the tin compound, the system was further stirred and refluxed for 24 hours. After complete solvent evaporation an oily compound was obtained, which was washed with 1:1 hexane-chloroform mixture $(3 \times 2 \mathrm{~mL})$ and dried at $100{ }^{\circ} \mathrm{C}$ in an Abderhalden pistol for $1 \mathrm{~h}$, with all manipulations performed in air, allowing the attainment of a white solid.

The complex $\left[\mathrm{BuSnLCl}_{2}\right]$ was characterized by the IR spectrum, by elemental analysis of carbon, hydrogen, chlorine and tin, by ${ }^{119 m}$ Sn-Mössbauer and ${ }^{119 m} \mathrm{Sn}-\mathrm{NMR}$ spectroscopic studies and by TG and DSC techniques.

\section{RESULTS AND DISCUSSION}

The complex $\left[\mathrm{BuSnLCl}_{2}\right]$ was observed using optical microscope and a microcrystalline constitution was exhibited by the complex. As it was observed for other organotin derivatives previously prepared by $\mathrm{us}^{2-5}$, it was not possible to obtain suitable single crystals to determine their structure by X-ray crystallography too.

The melting point observed for the $\left[\mathrm{BuSnLCl}_{2}\right]$ was $151-152{ }^{\circ} \mathrm{C}$; the results of elemental analysis were $\mathrm{C}=27.2 \%, \mathrm{H}=4.3 \%, \mathrm{Cl}=19.0 \%$ and $\mathrm{Sn}=33.5 \%$ in agreement with the calculated values $\mathrm{C}=27.5 \%, \mathrm{H}=4.6 \%, \mathrm{Cl}=20.3 \%$, and $\mathrm{Sn}$ $=33.9 \%$.

The most representative stretching vibrations from the infrared spectrum of the $\alpha$-hydroxyisobutyric acid, in $\mathrm{cm}^{-1}$, were $v_{\text {coOasym }}=1740 ; v_{\mathrm{COOsym}}=1280 ; \mathrm{V}_{\mathrm{OH}}$ $=3430$; and from the infrared spectrum of the $\left[\mathrm{BuSnLCl}_{2}\right]$, in $\mathrm{cm}^{-1}$, were $\mathrm{v}_{\text {coOasym }}$ $=1655,1563 ;{ }_{\text {COOsym }}=1310 ;{ }^{V}$ OH $=3200 ;{ }_{\mathrm{CH}}=2950,2900,2850 ;{ }_{\mathrm{SnO}}=480$; $\mathrm{V}_{\mathrm{SnCl}}=270,280$.

The observed alteration of the ${ }^{\nu}$ coosym value from $1740 \mathrm{~cm}^{-1}$ in the $\alpha$ hydroxycarboxylic acid ${ }^{9,10}$, to 1655 and to $1620 \mathrm{~cm}^{-1}$ in the complex, indicates the participation of the carboxyl of the $\alpha$-hydroxyisobutyric acid in the coordination to the tin. ${ }^{11}$ Similar results were obtained for the other compounds $\left[\left(\mathrm{LR}_{2} \mathrm{Sn}\right)_{2} \mathrm{O}\right]\{\mathrm{R}=\mathrm{Me}, \mathrm{Bu} ; \mathrm{L}=\mathrm{PhCH}(\mathrm{OH}) \mathrm{COO}\}_{3,4}$ and for the compounds $\left[\mathrm{R}_{2} \mathrm{SnL}_{2}\right]\left\{\mathrm{R}=\mathrm{Bu}, \mathrm{Ph} ; \mathrm{L}=\mathrm{MeOC}_{6} \mathrm{H}_{4} \mathrm{CH}(\mathrm{OH}) \mathrm{COO}, \mathrm{PhCH}(\mathrm{OH}) \mathrm{COO}\right\}^{7}$ studied by us. In a complementary form, the dislocation of the $\nu_{O H}$ from $3430 \mathrm{~cm}^{-1}$ in the $\alpha$-hydroxyisobutyric acid to $3200 \mathrm{~cm}^{-1}$ in the complex, suggests the existence of strong intramolecular hydrogen bonding, indicating an absence of the alcoholic hydroxyl group in the coordination of the tin atom.12-14

In the ${ }^{119 m}$ Sn Mössbauer spectroscopy, a single quadrupole splitting doublet was observed, making evident that $\left[\mathrm{BuSnLCl}_{2}\right]$ was present at only one site around the tin atom. The values for the quadrupole splitting doublet, $\Delta=1.92$ $\mathrm{mm} \mathrm{s}^{-1}$, and isomer shift, $\delta=1.02 \mathrm{~mm} \mathrm{~s}^{-1}$, are consistent with the tin atoms located in site with coordination number equal to four, which is highlighted by the relationship around the value $\rho=\Delta / \delta=1.93 . .^{15-18}$ The Mössbauer spectrum for the compound is presented in Figure 1. 


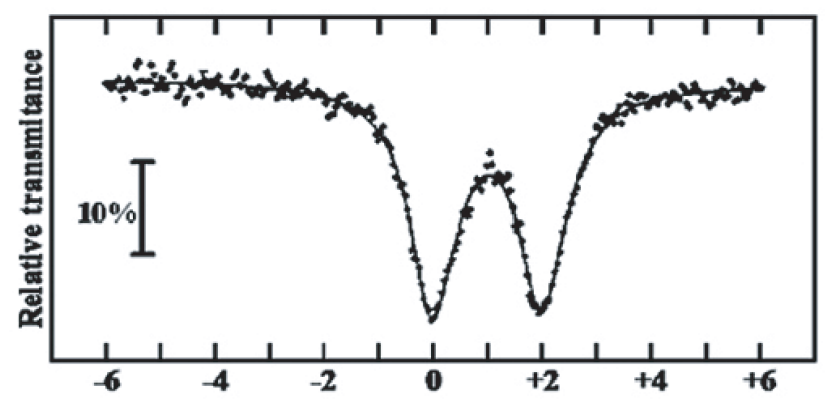

Figure 1: Mössbauer spectrum of $\left[\mathrm{BuSnLCl}_{2}\right], \mathrm{L}=\left(\mathrm{CH}_{3}\right)_{2} \mathrm{C}(\mathrm{OH}) \mathrm{COO}$, obtained at $\mathrm{T}=85 \mathrm{~K}$, using a $\mathrm{CaSnO}_{3}$ source at room temperature.

The presented data allowed the design of the proposed formulation and the structure of [ $\left.\mathrm{BuSnLCl}_{2}\right]$, a tetrahedral tin species, as it is shown in Figure 2. ${ }^{19-20}$<smiles>CC1(C)O[CH]OC1O[Sn](Cl)(Cl)Br</smiles>

Figure 2: Proposed structure for $\left[\mathrm{BuSnLCl}_{2}\right], \mathrm{L}=\left(\mathrm{CH}_{3}\right)_{2} \mathrm{C}(\mathrm{OH}) \mathrm{COO}$.

For the compound $\left[\mathrm{BuSnLCl}_{2}\right]$ it was possible to obtain the ${ }^{119 m} \mathrm{SnNMR}$ spectrum only in $\mathrm{C}_{5} \mathrm{D}_{5} \mathrm{~N}$, presented in Figure 3. In this spectrum one unexpected absorption signal $\delta\left({ }^{119 m} \mathrm{Sn}\right)$ at $-421.88 \mathrm{ppm}$ was observed, indicating a coordination number higher than four for the tin atom. As the spectrum was obtained in the environment of deuterated pyridine, it is possible to obtain coordination of the solvent to the tin, justifying the dislocation of the sign for a higher field. This is justifiable by the increase in the coordination numbers from 4 to 5 , or even to 6 , corresponding to a large screening of the tin nucleus. ${ }^{19,20}$

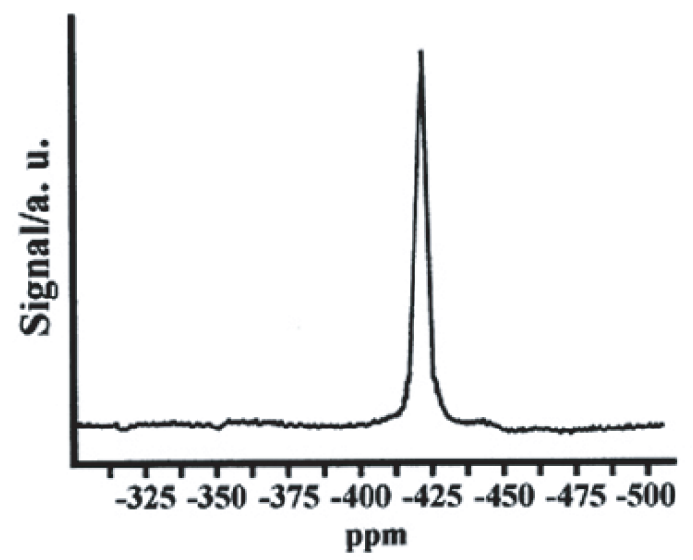

Figure 3: ${ }^{119 m} \mathrm{Sn}-\mathrm{NMR}$ spectrum of the $\left[\mathrm{BuSnLCl}_{2}\right], \mathrm{L}=\left(\mathrm{CH}_{3}\right)_{2} \mathrm{C}(\mathrm{OH}) \mathrm{COO}$ $\left(400 \mathrm{MHz}, \mathrm{C} \mathrm{D}_{5} \mathrm{~N}\right)$.

TG curve of the $\left[\mathrm{BuSnLCl}_{2}\right]$ obtained in dynamic helium atmosphere is presented in Figure 4. The initial and final temperatures of thermal decomposition process are 106 and $369{ }^{\circ} \mathrm{C}$, respectively. From $3.699 \mathrm{mg}$ of the complex we obtained $1.255 \mathrm{mg}(33.9 \%)$ of a final residue, in accordance with the theoretical tin content $(33.9 \%)$ of the compound. The formation of tin metal as the final product is proved by X-ray fluorescence.

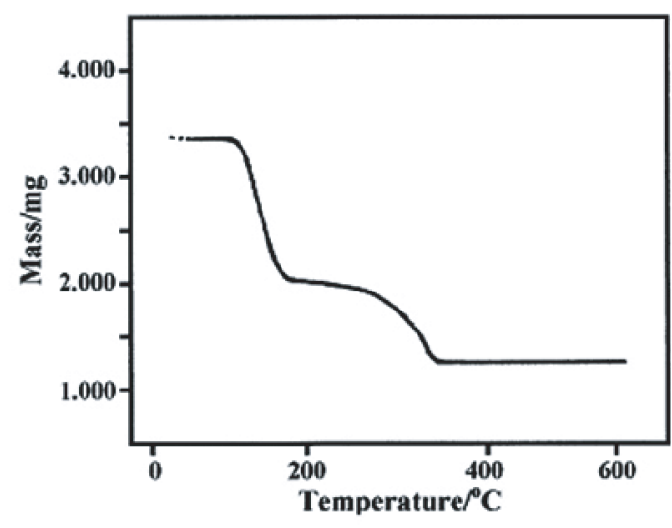

Figure 4: TG curve of $\left[\mathrm{BuSnLCl}_{2}\right], \mathrm{L}=\left(\mathrm{CH}_{3}\right)_{2} \mathrm{C}(\mathrm{OH}) \mathrm{COO}$.

For the compound [BuSnLC12], the TG curve suggests that the thermal decomposition proceeds in two steps consecutively. In the first step there is a loss of mass of $45.2 \%$ in the range $106-177^{\circ} \mathrm{C}$, and in the second step, a loss of mass of $20.3 \%$ with final temperature of $350{ }^{\circ} \mathrm{C}$, in agreement with the loss of butyl and $\alpha$-hydroyisobutyrate ligands in the first step and by loss of the two chlorides in the second step. Based on these observations it is possible to establish a tentative mechanism of their thermal decomposition, as indicated.

$$
\left[\mathrm{BuSnLCl}_{2}\right] \stackrel{106-177^{\circ} \mathrm{C}}{\longrightarrow}: \mathrm{SnCl}_{2}: \stackrel{192 \cdot-350^{\circ} \mathrm{C}}{\longrightarrow} \mathrm{Sn}
$$

The DSC curve of the $\left[\mathrm{BuSnLCl}_{2}\right]$ is presented in Figure 5. The temperature value abserved at the peak $\left(T_{\text {onset }}\right)$ is $147.2{ }^{\circ} \mathrm{C}$, according to the corresponding melting point of the compound, $151-152{ }^{\circ} \mathrm{C}$, and its calculated heat fusion is $\Delta \mathrm{H}_{\text {fusion }}=-13,4 \mathrm{~kJ}$ mol-1.

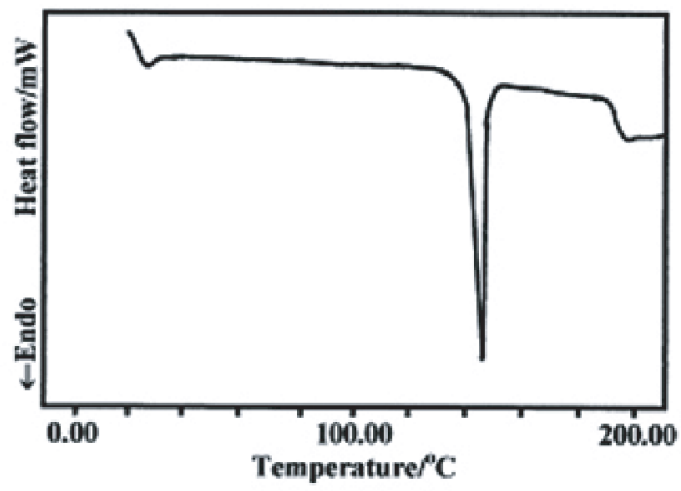

Figure 5: DSC curve of $\left[\mathrm{BuSnLCl}_{2}\right], \mathrm{L}=\left(\mathrm{CH}_{3}\right)_{2} \mathrm{C}(\mathrm{OH}) \mathrm{COO}$.

\section{CONCLUSION}

The studied compound $\left[\mathrm{BuSnLCl}_{2}\right], \mathrm{L}=\left(\mathrm{CH}_{3}\right)_{2} \mathrm{C}(\mathrm{OH}) \mathrm{COO}$, exists as tetrahedral tin species in solid-state, with the ligand $\alpha$-hydroxyisobutyrate monocoordinated to the tin atom only by deprotonated oxygen atom of the hydroxyl acid group, while the hydrogen atom of the alcoholic hydroxyl group forms a strong intramolecular hydrogen bond. The ${ }^{119 m} \mathrm{Sn}-\mathrm{NMR}$ spectrum in $\mathrm{C}_{5} \mathrm{D}_{5} \mathrm{~N}$ suggests the existence of a penta- or hexacoordinated tin species in solution, which can be explained by an eventual coordination of solvent molecules with the tin atom.

\section{ACKNOWLEDGEMENTS}

The authors are grateful to Dr. Carlos Alberto L. Filgueiras, of the Universidade Federal do Rio de Janeiro, and Dr. Anuar Abras, of the Universidade Federal de Minas Gerais, for experimental support; and to FAPEMIG (Fundação de Amparo à Pesquisa do Estado de Minas Gerais, Brazil) for financial support. 


\section{REFERENCES}

1. B. Y. K. Ho, J. J. Zuckerman, Inorg. Chem., 12, 1552, (1973).

2. V. R. Terra, Doctoral Program in Inorganic Chemistry, UFMG, (1997).

3. V. R. Terra, Roberto Santos Barbiéri, P. de A. Castelo Branco, A. Abras, Ecl. Quím., 23, 17, (1998).

4. Roberto Santos Barbiéri, V. R. Terra, A. K. C. Dias, M. G. Cardoso, J. Therm. Anal. Cal., 67, 453, (2002).

5. Roberto Santos Barbiéri, A. K. C. Dias, S. F. Silva, V. R. Terra, E. P. Lima, J. Therm. Anal. Cal., 79, 255, (2005).

6. E. T. Araujo, W. C. Melo, M. C. Guerreiro, Roberto Santos Barbiéri, C. M. P. Abreu, Ciênc. Agrotec., 28, 34, (2004).

7. Roberto Santos Barbiéri, S. F. Silva, E. P. Lima, A. K. C. Dias, M. G. Cardoso, V. R. Terra, Rev. Cient. Faminas, 1, 21, (2005).

8. Roberto S. Barbiéri, E. P. Lima, S. F. Silva, A. K. C. Dias, M. G. Cardoso, V. R. Terra. Ciênc. Agrotec., 30, 467, (2006).

9. R. M. Silverstein, F. X. Webster, D. Kiemle, Spectrometric Identification of Organic Compounds, $7^{\text {th }}$ ed., Wiley, New York, (2005).

10. J. A. Dean, Handbook of Organic Chemistry, $2^{\text {nd }}$ ed., McGraw-Hill, New York, (2004).
11. R. F. de Farias, L. M. Nunes, C. Airoldi, J. Therm. Anal. Cal., 74, 923, (2003).

12. G. F. Souza, C. A. L. Filgueiras, M. Y. Darensbourg, J. H. Reibenspies, Inorg. Chem., 31, 3944, (1992).

13. E. F. Assis, Doctoral Program in Inorganic Chemistry, UFMG, (1989).

14. G. F. Sousa, A. Abras, C. A. L. Filgueiras, Il Nuovo Cimento, 50, 79, (1996)

15. I. Omae, Organotin Chemistry, $2^{\text {nd }}$ ed., Elsevier, Amsterdam, (2004).

16. Alwyn G. Davies, Organotin Chemistry, Wiley-VCH, Mörlenbach, (2004).

17. Farooq Ali Shah, Shaista Sabir, Kaneez Fatima, Saqib Ali, Ishtiaq Qadri, Corrado Rizzolie, Dalton Trans., 10467, (2015).

18. Aboubacar Sidiki Sougoule, Cheick Abdoul balde, Namory Keita, Xiao Xio, Xiao Han, Jingwen Liang, Dongsheng Zhu, Heteroatom Chem., 26, 382, (2015)

19. R. S. Barbiéri, H. O. Beraldo, C. A. L. Filgueiras, A. Abras, J. F. Nixon, P. B. Hitchcock, Inorg. Chim. Acta, 169, 206, (1993).

20. Muhammad Ashfaq, Muhammad Mahboob Ahmed, Salama Shaheen, Rukhsana Tabussam, Gildardo Rivera, Quím. Nova, 39, 19, (2016). 